\title{
Investigating The Correlation Between Gender Of The Teacher And Fathers' Parental Involvement In Elementary Classrooms
}

Zafer Unal, University of South Florida, St. Petersburg, USA Aslihan Unal, Usak University, Turkey

\begin{abstract}
The purpose of this study was to investigate if there is a relationship between the genders of teachers when it comes to fathers' involvement in their children's schooling in elementary classrooms. We attempted to answer the following questions: 1) Are the fathers less/more involved when the teacher is female? 2) Are the fathers less/more involved when the teacher is male? 3) Is there a correlation between the gender of the teacher and fathers' involvement?
\end{abstract}

Keywords: Parental Involvement, Parental Involvement for Student Achievement

\section{INTRODUCTION}

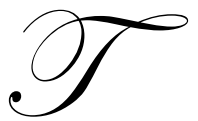

he importance of parent involvement in children's education has long been established. Research over the last two decades has demonstrated that children whose parents are involved are more likely than other youths to have positive educational outcomes, such as improved academic performance, better school attendance, higher aspirations, reduced dropout rates, and increased graduation rates (Catsambis, 1998; Desimone,1999; Keith et al. 1986; Ma 1999; McNeal 1999; Miedel and Reynolds 1999; Nord and West 2001; Trusty 1999). Decades of research confirms that students' family and home environment are among the greatest influences on their academic achievement and success (Coleman, et. al., 1966; Henderson \& Mapp, 2002; Wang, Haertel, \& Walberg, 1993).

There are numerous studies which focus on gender issues regarding parental involvement, suggesting that mothers are more willing to be involved in their children's education than fathers (National Center for Education Statistics, 1997; Gatto, 1998; Nord, Brimhall \& West, 1997; Nord 1999). Study after study shows that fathers are less involved than mothers. This issue became very noticeable in 1995 when President Clinton issued a memorandum requesting that all executive departments and agencies make a concerted effort to include fathers in their programs, policies, and research programs where appropriate and feasible(National Center for Education Statistics, 1997).

When studies indicated that fathers were less involved, researchers tried to answer the big question, "Why are fathers not more involved in their children's education?" Perhaps the largest study attempting to answer this question would be The National Household Education Survey of 1996 (discussed in NCES, 1997) which collected data on the academic achievement of students and their families' involvement in their schools during the first quarter of 1996. Phone interviews were conducted with parents and guardians of over 20,700 children from age three years to $12^{\text {th }}$ grade. Following is what the survey found to be the reasons for less father involvement:

- $\quad$ Fathers ranked institutional practices and barriers imposed by the workplace as the most important reasons for their low levels of involvement. 
- When parents are invited to the schools or centers, fathers are less likely, on average, to respond to these invitations for involvement. Part of the reason is that parents often assume that such invitations are for mothers only because, though incorrect, the word parent in the school context and others has often been interpreted to mean mother.

- $\quad$ Some fathers can't read or are functionally illiterate. They are embarrassed to come to school and interact with educators because they lack, or may believe they lack, these necessary communication skills.

- $\quad$ Parents generally, and fathers specifically, may not know how to assist their children with their education. They can be intimidated by new, unfamiliar course content, higher expectations for learning, and computer technology. Their response may be to do nothing.

The above reasons for fathers' lack of parental involvement in two-parent families are repeated and also confirmed by other studies. However, at the time of this study, there was no reference found on how, if any, gender of the teacher plays a role in the amount of fathers' involvement. This study investigated if there is a relationship between the genders of the teachers when it comes to fathers' involvement in their children's schooling in Turkish elementary classrooms. The study attempted to answer the following questions:

- $\quad$ Are the fathers less/more involved when the teacher is female?

- $\quad$ Are the fathers less/more involved when the teacher is male?

- Is there a correlation between the gender of the teacher and fathers' involvement?

\section{METHODOLOGY}

Data in this study were collected from 33 teachers and 232 parents (only fathers) in three elementary schools in a southern city of Turkey using two paper-based surveys. After obtaining the human subjects' approval, the researcher visited three public elementary schools and consulted school principals to conduct the surveys.

During this conversation, the study was described, anonymity of the participants guaranteed, and permission was requested to contact teachers and distribute the parent surveys. With approval received from each principal, the researchers first surveyed the teachers in their classrooms and then asked them to deliver parent surveys via their students. The parent survey included consent forms indicating that the responses would not affect students' schoolwork or grades. Teachers and parents were also reminded that only fathers were asked to fill out the survey, regardless of their level of parental involvement.

The instrument used in this study was a modified version of Epstein \& Salinas (1993) "School and Family Partnership" survey. Permission for the translation and use of the survey was also obtained from the authors of the surveys. The questionnaire consisted of four parts: (1) demographic questions, (2) questions related to perspectives of teachers and parents (fathers) on parental involvement, (3) questions related to perspectives of teachers and parents (fathers) on the role of gender in parental involvement, and (4) open-ended questions on how to increase parental involvement. Even though the teacher surveys were collected at the time of the first visit, each school was later (two weeks) visited to obtain the survey results from the parents. The return rate of the distributed survey was $100 \%$ teachers $(33 / 33)$ and $20 \%$ parents - fathers (232/1155). The data later were entered in SPSS to analyze and answer the research questions.

\section{RESULTS}

\section{Section 1: Demographics of Participants}

The first section of the parent-teacher survey collected information about the demographics of the study participants. The results indicated age, gender, level of education, grades taught, the grades the children are in, and years of teaching experience. The results are provided in Table 1. 
Table 1: Demographic Information of Study Participants

\begin{tabular}{|c|c|}
\hline Teachers $(n=33)$ & Fathers $(n=232)$ \\
\hline Age & Age \\
\hline Mean: 31.66 SD: 7.15 & Mean: 35.87 SD: 9.18 \\
\hline \multicolumn{2}{|l|}{ Gender } \\
\hline \multicolumn{2}{|l|}{ Males: 12} \\
\hline \multicolumn{2}{|l|}{ Females: 21} \\
\hline Education & Education \\
\hline College: 31 & Elementary School: 74 \\
\hline \multirow[t]{3}{*}{ Graduate Degree: 2} & Middle School: 93 \\
\hline & High School: 56 \\
\hline & College: 16 \\
\hline Grades Taught & Grades Children In \\
\hline Grade 1: 6 & Grade 1: 42 \\
\hline Grade 2: 5 & Grade 2: 33 \\
\hline Grade 3: 8 & Grade 3: 61 \\
\hline Grade 4: 7 & Grade 4: 59 \\
\hline Grade 5: 7 & Grade 5: 37 \\
\hline \multicolumn{2}{|l|}{ Years of Teaching Experience } \\
\hline \multicolumn{2}{|l|}{ Mean: 9.42} \\
\hline SD: 7.51 & \\
\hline
\end{tabular}

\section{Section 2: Perspectives of Teachers and Parents (Fathers) on Parental Involvement}

The second section of the parent-teacher survey collected information about the perspectives of teachers and parents (fathers) on parental involvement. The results (Table 2) indicate that both parents and teachers agree on the importance of parental involvement and its positive effect on students' learning and contributions in school. An Independent Samples t-test in SPSS was used to see if the responses of the groups (teachers and parents) had a significant difference. Although the results showed that both teachers and parents agreed on all of the items, it can be observed that parents seem to believe in parental involvement more than the teachers (they scored higher than teachers on each item). However, this difference is statistically insignificant.

Table 2: Opinions of Teachers and Parents on Parental Involvement

\begin{tabular}{|c|c|c|c|c|c|c|c|}
\hline \multirow{2}{*}{ Items } & \multicolumn{2}{|c|}{ Teachers } & \multicolumn{2}{|c|}{ Parents } & \multicolumn{3}{|c|}{ Significance } \\
\hline & Mean & SD & Mean & SD & $\mathbf{t}$ & df & Sig \\
\hline $\begin{array}{l}\text { Parental involvement can help teachers be more effective } \\
\text { with more students }\end{array}$ & 4.45 & .506 & 4.51 & .501 & -626 & 263 & .532 \\
\hline $\begin{array}{l}\text { Parental involvement is important for student success in } \\
\text { school }\end{array}$ & 4.45 & .617 & 4.52 & .596 & -563 & 263 & .574 \\
\hline $\begin{array}{l}\text { Parental involvement can help teachers be more effective } \\
\text { with more students }\end{array}$ & 4.36 & .699 & 4.40 & .669 & -263 & 263 & .793 \\
\hline Parental involvement can help students stay in school & 4.52 & .566 & 4.58 & .545 & -613 & 263 & .540 \\
\hline Soru 5 & 4.42 & .502 & 4.47 & .500 & -444 & 263 & .658 \\
\hline
\end{tabular}

Interpretation Scale: Strongly Disagree (1), Disagree (2), Neutral (3), Agree (4), Strongly Agree (5).

$* \mathrm{p}<.05$ (Independent sample t-test)-Significant Difference

\section{Section3. Perspectives of Teachers and Parents (Fathers) on Parental Involvement}

The next section of the survey consisted of questions directed to both teachers and parents (fathers) about their perspectives on how their gender affects the level of parental involvement. When analyzing, researchers divided Section 3 into two groups to compile meaningful results, bringing different themes. 
Table 3: Perspective of Teachers on Fathers' Parental Involvement

\begin{tabular}{|c|c|c|c|}
\hline Statement & Female Teachers & Male Teachers & Significance \\
\hline $\begin{array}{l}\text { I believe that fathers' involvement is as important as mothers for } \\
\text { students' success }\end{array}$ & $\begin{array}{l}\mathrm{M}=4.29 \\
\mathrm{SD}=.784\end{array}$ & $\begin{array}{l}\mathrm{M}=4.50 \\
\mathrm{SD}=.522\end{array}$ & $\begin{array}{l}\mathrm{t}=-843 \\
\mathrm{Sig}=.406\end{array}$ \\
\hline I believe that fathers feel comfortable when they visit my classroom & $\begin{array}{l}\mathrm{M}=1.76 \\
\mathrm{SD}=.768\end{array}$ & $\begin{array}{l}\mathrm{M}=3.52 \\
\mathrm{SD}=.798\end{array}$ & $\begin{array}{l}\mathrm{t}=6.166 \\
\text { Sig }=.000 *\end{array}$ \\
\hline $\begin{array}{l}\text { Parental involvement in my classroom mostly consists of male } \\
\text { parents }\end{array}$ & $\begin{array}{l}\mathrm{M}=1.57 \\
\mathrm{SD}=.926\end{array}$ & $\begin{array}{l}\mathrm{M}=3.50 \\
\mathrm{SD}=1.087\end{array}$ & $\begin{array}{l}\mathrm{t}=5.402 \\
\mathrm{Sig}=.000 *\end{array}$ \\
\hline $\begin{array}{l}\text { I try to encourage fathers to attend parent-teacher conferences by } \\
\text { making the invitations appealing to fathers as well }\end{array}$ & $\begin{array}{l}\mathrm{M}=2.90 \\
\mathrm{SD}=.768\end{array}$ & $\begin{array}{l}\mathrm{M}=2.92 \\
\mathrm{SD}=.864\end{array}$ & $\begin{array}{l}\mathrm{t}=.660 \\
\text { Sig }=.968\end{array}$ \\
\hline $\begin{array}{l}\text { I try to encourage fathers to attend parent-teacher conferences by } \\
\text { scheduling meetings other than work days/hours (weekend or after } \\
5 \mathrm{pm} \text { ) }\end{array}$ & $\begin{array}{l}\mathrm{M}=2.71 \\
\mathrm{SD}=1.056\end{array}$ & $\begin{array}{l}\mathrm{M}=3.08 \\
\mathrm{SD}=.900\end{array}$ & $\begin{array}{l}\mathrm{t}=-1.017 \\
\mathrm{Sig}=.317\end{array}$ \\
\hline $\begin{array}{l}\text { I try to involve parents from different genders by having an assistant } \\
\text { of opposite gender present during conferences }\end{array}$ & $\begin{array}{l}\mathrm{M}=1.76 \\
\mathrm{SD}=.700\end{array}$ & $\begin{array}{l}\mathrm{M}=2.08 \\
\mathrm{SD}=.712\end{array}$ & $\begin{array}{l}\mathrm{t}=1.143 \\
\mathrm{Sig}=.262\end{array}$ \\
\hline $\begin{array}{l}\text { I believe my gender has a direct affect on the gender of parents } \\
\text { involved in my classroom }\end{array}$ & $\begin{array}{l}\mathrm{M}=4.38 \\
\mathrm{SD}=1.02\end{array}$ & $\begin{array}{l}\mathrm{M}=4.58 \\
\mathrm{SD}=.870\end{array}$ & $\begin{array}{l}\mathrm{t}=1.110 \\
\mathrm{Sig}=.276\end{array}$ \\
\hline
\end{tabular}

Interpretation Scale: Strongly Disagree (1), Disagree (2), Neutral (3), Agree (4), Strongly Agree (5).

$* \mathrm{p}<.05$ (Independent sample t-test)-Significant Difference

The first division given in Table 3 displays the data on how female and male teachers describe the effects of gender and how it affects the amount of parental involvement coming from different genders. The researchers also used an Independent Samples t-test to compare the responses of two groups for their significance.

The results of this section provide that both female and male teachers agree on the positive effects of fathers' involvement. They both believe that fathers' involvement is as important as mothers for students' success and they try to encourage fathers to attend parent-teacher conferences by making the invitations appealing to fathers, having an assistant of opposite gender present during conferences. Also, teachers from either gender believe that their gender has a direct affect on the genders of parents involved in their classrooms. However, there is a significant difference between the responses to the second and third questions of male and female teachers, indicating that male teachers are more appealing and comforting to the fathers. In other words, male teachers have more fathers involved in their classroom than female teachers and fathers find male teachers more comforting.

The second division given in Table 4 displays the data on how fathers with female and male teachers describe the effects of gender and how it affects the amount of their parental involvement. The researchers used an Independent-Samples t-test to compare the responses of two groups for their significance.

Table 4: Perspective of Fathers on Fathers' Parental Involvement

\begin{tabular}{|c|c|c|c|}
\hline Statement & $\begin{array}{c}\text { Fathers with } \\
\text { Female Teachers }\end{array}$ & $\begin{array}{c}\text { Fathers with } \\
\text { Male Teachers }\end{array}$ & Significance \\
\hline $\begin{array}{l}\text { I believe that fathers' involvement is as important as mothers for } \\
\text { students' success }\end{array}$ & $\begin{array}{l}\mathrm{M}=3.99 \\
\mathrm{SD}=.754\end{array}$ & $\begin{array}{l}\mathrm{M}=4.06 \\
\mathrm{SD}=.697\end{array}$ & $\begin{array}{l}\mathrm{t}=-.855 \\
\mathrm{Sig}=.393\end{array}$ \\
\hline I feel comfortable when I visit my child's classroom & $\begin{array}{l}\mathrm{M}=2.65 \\
\mathrm{SD}=1.065\end{array}$ & $\begin{array}{l}\mathrm{M}=3.83 \\
\mathrm{SD}=.859\end{array}$ & $\begin{array}{l}\mathrm{t}=-7.09 \\
\mathrm{Sig}=.000 *\end{array}$ \\
\hline $\begin{array}{l}\text { Parental involvement in my child's classroom mostly consists of } \\
\text { my participation rather than that of my wife }\end{array}$ & $\begin{array}{l}\mathrm{M}=2.33 \\
\mathrm{SD}=1.010\end{array}$ & $\begin{array}{l}\mathrm{M}=3.79 \\
\mathrm{SD}=.898\end{array}$ & $\begin{array}{l}\mathrm{t}=-9.115 \\
\mathrm{Sig}=.000^{*}\end{array}$ \\
\hline $\begin{array}{l}\text { I feel encouraged when my child's teacher tries to involve fathers } \\
\text { to attend parent-teacher conferences by making the invitations } \\
\text { appealing to fathers as well }\end{array}$ & $\begin{array}{l}\mathrm{M}=3.31 \\
\mathrm{SD}=.751\end{array}$ & $\begin{array}{l}M=3.15 \\
S D=.714\end{array}$ & $\begin{array}{l}\mathrm{t}=1.360 \\
\mathrm{Sig}=.175\end{array}$ \\
\hline $\begin{array}{l}\text { I feel more encouraged when my child's teacher schedules } \\
\text { meetings other than the work days/hours (weekend or after } 5 \mathrm{pm} \text { ) }\end{array}$ & $\begin{array}{l}\mathrm{M}=4.57 \\
\mathrm{SD}=.496\end{array}$ & $\begin{array}{l}\mathrm{M}=4.62 \\
\mathrm{SD}=.489\end{array}$ & $\begin{array}{l}\mathrm{t}=.678 \\
\text { Sig }=.499\end{array}$ \\
\hline $\begin{array}{l}\text { I would feel more encouraged if my child's teacher is a female and } \\
\text { have an assistant of opposite gender present during conferences }\end{array}$ & $\begin{array}{l}\mathrm{M}=4.52 \\
\mathrm{SD}=.512\end{array}$ & $\begin{array}{l}\mathrm{M}=4.33 \\
\mathrm{SD}=.834\end{array}$ & $\begin{array}{l}\mathrm{t}=1.146 \\
\mathrm{Sig}=.253\end{array}$ \\
\hline $\begin{array}{l}\text { I believe the gender of the teachers has a direct affect on the level } \\
\text { of my parental involvement }\end{array}$ & $\begin{array}{l}\mathrm{M}=4.14 \\
\mathrm{SD}=.498\end{array}$ & $\begin{array}{l}\mathrm{M}=4.52 \\
\mathrm{SD}=.505\end{array}$ & $\begin{array}{l}\mathrm{t}=3.370 \\
\mathrm{Sig}=.001 *\end{array}$ \\
\hline
\end{tabular}

Interpretation Scale: Strongly Disagree (1), Disagree (2), Neutral (3), Agree (4), Strongly Agree (5).

$* \mathrm{p}<.05$ (Independent sample t-test)-Significant Difference 
The results of this section provide that both fathers with female and male teachers in their children's classrooms agreed on the positive effects of their involvement. They both believe that fathers' involvement is as important as mothers for students' success and they are encouraged to attend parent-teacher conferences when teachers try to make the conferences invitations appealing to fathers, when female teachers have a male assistant during conferences and, most importantly (highest scores), when teachers schedule conferences for off-day hours (nights and weekends). However, it can be concluded that fathers with female teachers feel less comfortable visiting their children's classrooms than fathers with male teachers. The t-test also confirms the significance of the two groups on this item. Finally, father with male teachers indicate higher parental involvement than fathers with female teachers, and fathers with male teachers believe stronger that the gender of teacher has a direct affect on the level of their involvement than that of female teachers.

The final section of the survey included open-ended questions for both teachers and parents asking about their opinions/perspectives on father's parental involvement (Table 5).

Table 5: Themes derived from Responses to Open-Ended Questions

\begin{tabular}{|c|c|}
\hline Theme & Responses \\
\hline $\begin{array}{l}\text { Female and Male Teachers } \\
\text { believe that their gender } \\
\text { automatically welcomes parents } \\
\text { the same gender of parents }\end{array}$ & $\begin{array}{l}\text { Male Teacher: "I send invitation notes to the parents and include that both parents always } \\
\text { welcome in my classroom however, I get fathers most of the time. I think that is because I } \\
\text { am a man and mothers do not feel comfortable with me." } \\
\text { Female teacher: "I have observed throughout the years that mothers participate more than } \\
\text { fathers in my classroom with my students. Mothers mostly participate in conferences, } \\
\text { attend monthly meetings and volunteer for activities. I get fathers only If I specify each } \\
\text { student mother to bring the fathers as well. Even with that the participation is very low. I } \\
\text { can attribute this issue to my gender being female and mothers feel more conformable } \\
\text { with me." } \\
\text { Female teacher: "When fathers attend parent-teacher meetings, I try to make sure to } \\
\text { include them in the discussions. However, too often fathers feel as if they were the } \\
\text { invisible figure at what was, in effect, a "'mother-teacher" meeting." }\end{array}$ \\
\hline $\begin{array}{l}\text { Fathers with male teachers feel } \\
\text { more comfortable in parental } \\
\text { involvement than that of female } \\
\text { teachers and they suggest } \\
\text { increase on male teachers }\end{array}$ & $\begin{array}{l}\text { Father with Female Teacher: "My wife communicates with my son's teacher much better } \\
\text { than me and she is happy to do it. I try to work with my son at home and help him as much } \\
\text { as I can." } \\
\text { Father with Female Teacher: "I agree that fathers should be involved in their children's } \\
\text { education. However, schools teachers shouldn't make fathers feel guilty, if they don't have } \\
\text { sufficient time or energy to be involved in their children's lives. Also, my wife does a great } \\
\text { job being involved with the school activities and I help my kid at home. I just do not feel } \\
\text { that I physically have to be in the classroom meeting with the teacher." } \\
\text { Father with Female Teacher: "Perhaps it would help if we had more male teachers to } \\
\text { offset the domination of women in children's education. Too many men give in to the } \\
\text { feminist plan to make them redundant." } \\
\text { Father with Male Teacher: "I believe that my daughter definitely benefits from my } \\
\text { involvement in their education. I feel very comfortable and I can talk with her teacher } \\
\text { about anything." } \\
\text { Father with Male Teacher: "I believe that fathers should certainly be more involved in } \\
\text { their children's schooling. Parental involvement is a contributing factor to a child's well } \\
\text { being and overall mental health. With both parents working in many families, children } \\
\text { need the added assurances provided by fathers involved in their education." }\end{array}$ \\
\hline
\end{tabular}




\section{DISCUSSION \& CONCLUSION}

Cotton and Wikelund (2001) revealed that parent involvement in children's learning is positively related to achievement. Also, the more intensively parents are involved in their children's learning, the more beneficial are the achievement effects. This holds true for all dimensions of parental involvement in children's learning and for all types and ages of students. This study once more confirms that both parents and teachers agree on the importance of parental involvement and the positive effects on students' success.

Levine (1993) outlined four factors that constrain Head Start and state-funded pre-kindergarten programs from encouraging father involvement: 1) fathers' fears of exposing inadequacies, 2) ambivalence of program staff members about fathers' involvement, 3) gate keeping by mothers, and 4) inappropriate program design and delivery. In this study, the researchers focused on mostly the gender differences between the teachers and parents and how they viewed their gender and its effects to the parental involvement. This study confirmed that there is a positive correlation between the gender of the teacher and the father's involvement, concluding that fathers are less involved when the teacher is female or more involved when the teacher is male.

The results of this study recommend that in order to increase fathers' involvement, each one of these barriers provided by Levine (1993) must be overcome as programs attempt to encourage and facilitate increased involvement of fathers in their children's school experiences. Also, fathers need to be given "credit" for their involvement. They need to be made aware of the benefits for their children when they are involved; i.e. higher grades, more extracurricular participation, reduced odds of suspension or expulsion from school, just to name a few.

While being a teacher is mostly popular with women, male teacher population is increasing too. According to NEA research, $24.9 \%$ of the nation's three million teachers are men. Michigan is ranked first in the percentage of male teachers (37\%). National Education Association Male Teacher Fact Sheet (2003) indicates that some countries have almost an equal number of male and female teachers in elementary schools. The results of this study show that the increase of male teachers would certainly have positive effects on fathers' involvement.

This study has certain limitations, such as a small sample of teachers (33) and it includes only three elementary schools. Replicate studies are recommended for educators to conduct their studies with a wider population. This study includes only fathers and wider studies can involve mothers as well.

This study is unique and it adds to the growing body of studies on fathers' involvement since it examines how the same or different gender of teacher and parent makes a difference on the level of parental involvement. The results of this study provide recommendations to teachers, parents, educators, and districts providing more insights on how to increase fathers' involvement.

\section{AUTHOR INFORMATION}

Zafer Unal is an Assistant Professor of Childhood Education, serving as assessment coordinator for the College of Education, coordinating the college wide assessment system at University of South Florida, St. Petersburg. Dr. Unal earned his doctorate degree in Elementary Education from Florida State University. His areas of research are using technology as an instructional tool, distance education, and assessment of teacher candidate learning and online portfolios. He teaches undergraduate and graduate courses.

Aslihan Unal is an Assistant Professor of Elementary Education for the College of Education, Usak University, Turkey. Dr. Unal earned his doctorate degree in Elementary Education from Florida State University. His areas of research are parental involvement, distance education and classroom management.

\section{REFERENCES}

1. Catsambis, S. (1998). Expanding the Knowledge of Parental Involvement in Secondary Education: Effects on High School Academic Success. Baltimore: Center for Research on the Education of Students Placed At Risk. (ERIC ED426174) 
2. Chan, D. W. (2008). General, collective, and domain-specific teacher self-efficacy among Chinese prospective and in-service teachers in Hong Kong. Teaching and Teacher Education, 24(4), 1057-1069.

3. Coleman, J. S., Campbell, E. Q., Hobson, C. J., McPartland, J., Mood, A. M., Weinfeld, F. D., \& Yourk, R. L. (1966). Equality of educational opportunity. Washington, DC: U.S. Government Printing Office.

4. Cotton, K., \& Wikelund, K.R. (2001). Parent involvement in education. Retrieved October 12, 2004, from Nortwest Regional Education Laboratory Web site: http:// www.nwrel.org/scpd/sirs/3/cu6.html

5. Desimone, L. (1999). Linking Parental Involvement With Student Achievement: Do Race and Income Matter? Journal of Educational Research, 93: 11-30.)

6. Epstein, J. L. \& Salinas, K.C. (1993). School and family partnership: Questionnaires for teachers and parents in elementary and middle grades. Baltimore, MD: Johns Hopkins University, Center on Families, Communities, Schools and Children's Learning.

7. Gatto, R. (1998). Parental involvement in schools. Review of "Fathers Involvement in Their Children's Schools".

8. Henderson, A., \& Mapp, K. L. (2002). A new wave of evidence: The impact of school, family, and community connections on student achievement. Austin, TX: Southwest Educational Development Laboratory.

9. $\quad$ Keith, T.Z., Reimers, T.M., Fehrmann, P.G., Pottebaum, S.M., and Aubey, L.W. (1986). Parental Involvement, Homework, and TV Time: Direct and Indirect Effects on High School Achievement. Journal of Educational Psychology, 78: 373-380.)

10. Levine, J.A. (1993). Involving Fathers in Head Start: A Framework for Public Policy and Program Development. Families in Society, 74(1): 4-19.

11. Ma, X. (1999). Dropping Out of Advanced Mathematics: The Effects of Parental Involvement. Teachers College Record, 101: 60-81.)

12. McNeal, R.B. (1999). Parental Involvement as Social Capital: Differential Effectiveness on Science Achievement, Truancy, and Dropping Out. Social Forces, 78: 117-144.)

13. Miedel, W.T. and Reynolds, A.J. (1999). Parental Involvement in Early Intervention for Disadvantaged Children: Does It Matter? Journal of School Psychology, 37: 379-402.)

14. National Center for Education Statistics. Statistical Analysis Report (1997). National Household Education Survey. Fathers' Involvement in Their Children's Schools. U.S. Department of Education. Office of Educational Research and Improvement NCES 98-091. http://nces.ed.gov/pubs98/98091.pdf

15. National Education Association Male Teacher Fact Sheet (2003). Retrieved on June 23, 2008 from http://www.nea.org/teachershortage/03malefactsheet.html ).

16. Nord, C. W. (1999). Father Involvement in Schools. ERIC Digest. http://www.ericdigests.org/19991/father.html

17. Nord, C. W., Brimhall, D., \& West, J. (1997). Fathers' Involvement in Their Children's Schooling (NCES 98-091). Washington, DC: U.S. Department of Education, National Center for Education Statistics. ED 409 125.

18. Nord, C.W and West, J. (2001). Fathers' and Mothers' Involvement in Their Children's Schools by Family Type and Resident Status (NCES 2001-032). U.S. Department of Education, National Center for Education Statistics. Washington, DC: U.S. Government Printing Office.)

19. Saban, A. (2003). A Turkish profile of prospective elementary school teachers and their views of teaching. Teaching and Teacher Education Volume 19, Issue 8, November 2003, Pages 829-846.

20. Trusty, J. (1999). Effects of Eighth-Grade Parental Involvement on Later Adolescents' Educational Expectations. Journal of Research and Development in Education, 32: 224-233.)

21. Wang, M. C., Haertel, G. D., \& Walberg, H. J. (1993). Toward a knowledge base for school learning. Review of Educational Research, 63, 249-294. 


\section{NOTES}

